\title{
Personal \& Professional Efficiency of University Teachers in Relation to their Professional Burnout
}

\author{
*Vijaya Anuradha, R; ** Shailaja, M; ***Lokanadha Reddy, G; **** Vijaya Vardhini, S \\ *Associate Professor, Indian College of Education, Katpadi -Tiruvalam Road, Katpadi, Vellore-14. \\ **Associate Professor, St. Mary's College of Education, Buchireddypalyam-524305, Nellore Dist .,A.P.State, \\ *** Former Vice-Chancellor (FAC), Dravidian University, Kuppam- 517 426, Chittoor Dist., A. P. State, India. \\ **** Associate Professor, Department of Education, Dravidian University, Kuppam -517426.
}

\begin{abstract}
Stress at work place is a barometer of the health of an organization. Prolonged stress in any employee leads to professional burnout. This study examined the relationship between professional burnout and occupational stress due to personal \& professional efficiency of teachers working at university level. Rating Scales were administered on a sample of 955 university teachers from 9 universities of Andhra Pradesh and Tamil Nadu who were chosen by using Simple Random Sampling Technique. The statistical techniques employed were percentage, mean, $S D$, mean $\pm 1 S D$, and also correlations computed to analyze the obtained data. Results of the study revealed that around $86 \%$ of university teachers are experiencing moderate and high levels of professional burnout and around $60 \%$ of them are showing moderate level of occupational stress due to personal \& professional efficiency. Further, correlation studies revealed that there is a significant positive relationship between professional burnout and occupational stress due to personal \& professional efficiency. The results reinforce the need for interventions in strengthening and reinforcing teacher's self-confidence and positive attitude, and weakening the stress and burnout causing factors. Much of the stress and burnout can be minimized through support, persistence, problem solving, active decision making and planning, organizational adaptability and developing good human relations.
\end{abstract}

Keywords:- Professional Burnout, Occupational Stress, Personal \& Professional Efficiency.

\section{INTRODUCTION}

Realizing the importance of global market, demands of the world society, the educational system is gearing up in India year by year to incorporate or introduce new concepts into different courses of higher education curriculum. Here, the roles and responsibilities of the teachers are vital in terms of acquiring information, knowledge, developing positive attitude towards the new world order, equipping with right skills and competencies and transform the same in turn to the student community to bring desired behaviors in them to meet the demands of the global environment. The universities have to perform multiple roles, like creating new knowledge, acquiring new capabilities and producing an intelligent human resource pool, through challenging teaching, research and extension activities so as to balance both the need and the demand. This change has urged academics to be responsive to the growing demands emphasizing on performance and professional standards, diverse student needs and expectations, high pressures on time and workload, a competitive research environment, declining public funding, and increased administrative and fiscal accountability (Houston et al., 2006). Several studies (McLaughlin et al., 1986; Guskey, 1984) indicate that change can lead teachers to question their own capacities and competencies. Change can evoke a wide range of concerns among teachers that relate to their personal role in the change, their ability to meet the demands of the change, the strategies necessary to implement the change and the likely effects of the change on their students and on other aspects of their work (Hall, 1996). Therefore, it could be argued that not only is the academic workplace changing rapidly, but also teachers are facing difficulties in managing the pressures of their work.

Teachers are perennially exposed to high levels of stress and burnout cutting across all cultures (Copper and Kelly, 1993; Reglin and Reitzammer, 1997; Chan 1998; Mokdad, 2005). It is a mental and physical condition which affects an individual's productivity, effectiveness, personal health and quality of work (Comish and Swindle, 1994). The combination of long working hours, insufficient pay, role ambiguity, poor teaching facilities, lack of social recognition, poor organizational climate, strained relationship with colleagues' makeup a stressful recipe which further extends to the state of burnout among teachers.

\section{Need for the Study}

Teachers are expected not only to work as pedagogues but also juggle multiple roles of an administrator, resource person, innovator, counselor, and role model for society which subsequently leads to high levels of stress and burnout. In the prevailing educational setup, teachers continue to reel under the pressure of working under too many constraints imposed by too many bodies, meeting the norms and standards, rules and regulations of concerned government, the ever changing eligibility criteria for becoming teachers and it's implications and their professional lives also acts as a stressor (Anuradha, 2012). Role under-load is the other role characteristic related to being stressed when a teacher's skills are underutilized. While role overload represents a demand, role under-load is characterized by constraint. Role under load is said to be present when teachers have too much ability for the job they hold. As early as 1911, in this discussion of scientific 
management, Taylor (1911) noted the negative effects that can arise when an individual is over skilled for a job.

When university teachers are exposed continually to high demand but limited resources, they will experience role pressure. Over extended exposure to this pressure and failure to use internal resources (self-efficacy) and situational resources (supports) will cause strain to occur. In their effort to reduce the feeling of strain, academics tend to have the feeling of low levels of professional efficacy. In other words, strain reduces professional efficacy when teachers are unable to perform academic tasks such as carrying out the teaching role effectively, evaluation, research and publishing journal articles since these tasks are part of their professional role.

Personal and professional efficacy refers to teachers' expectations of continued effectiveness at work (Schaufeli et al., 1996). An individual with low professional efficacy does not have a positive opinion of their work performance (Evers \& Tomic, 2003). It has been found that people suffering from burnout appeared to be less effective in their daily work, and work performance suffers because of negative work attitudes and behavior (Schaufeli, Maslach, \& Marek, 1993). Professional efficacy has been largely associated with various personality dimensions such as selfefficacy (Bandura, 1997; Cordes \& Doherty, 1993, Shirom, 1989), hardiness (Kobasa, 1979), and locus of control (Foqua \& Couture, 1986). The essential distinction between professional efficacy and self-efficacy is that professional efficacy is a measure of general confidence in one's ability to perform the job (Schaufeli et al., 1996), whereas selfefficacy refers to the perception of personal ability to perform specific component of the job (Schwarzer \& Schmitz, 2005). As documented by Leiter (1992), low selfefficacy is a cause of reduced professional efficacy. In this context, teachers with low self-efficacy cannot accomplish the given tasks. The feeling of competence that is a core element of professional efficacy will be lower. Bandura (1997) showed that teachers with high levels of selfefficacy persisted better in challenging tasks and tasks that involve responsibility. Cordes and Doherty (1993) suggested that low self-efficacy tends to make one feel incompetent to accomplish the given task, which would contribute to a low level of professional efficacy. The mastery experience that is normally a result of previous task accomplishment will strengthen self-efficacy beliefs (Bandura, 1997). With strong self-efficacy beliefs, teachers will be less fearful, less anxious and less tense, leading to increased levels of the feeling of competence at work. Kobasa (1979) proposed that teachers who possess a 'hardy personality' experience and respond to stressors in a more adaptive and effective way. Hsieh et al. (2004) found that levels of hardiness were positively correlated with professional efficacy. These empirical findings seem to suggest that professional efficacy is associated with those personality dimensions such as locus of control and selfesteem. People with low self-efficacy tend to have pessimistic thoughts about their performance and professional efficacy (Bandura, 1997).
The most serious implication of stress and burnout among teachers is the impact it has on the quality of teacher performance. Such stressed teachers cannot produce balanced and holistically developed students equipped to take on the challenges of the future. Ultimately it affects the quality of education in the country. Hence stress and burnout among teachers, particularly the university teachers ought to be a matter of grave concern for one and all. Also, the stressors operating in the lives of university teachers is a critical issue with far reaching implications, influencing not only the quality of teachers but also the quality of the nation at large, thereby gaining prominence in academic circles. In this backdrop the investigators felt the need to find out the stressors responsible for the burnout among university teachers in relation to their personal and professional efficiency and hence the research was carried out on this aspect.

\section{$>$ Objectives of the Study}

- To identify the level of professional burnout of university teachers.

- To assess the level of occupational tress of university teachers caused due to their personal and professional efficiency.

- To find out the number and percentage of university teachers with low, moderate and high levels of professional burnout and occupational stress caused due to their personal and professional efficiency.

- To find out the significant difference, if any, in the occupational stress of university teachers caused due to their personal and professional efficiency due to variations in their gender, age, educational qualification, community, designation, nature of the department they are working - in, years of experience, nature of job and average number of working hours per week.

- To find out the significant difference, if any, in the professional burnout of university teachers due to variations in their gender, age, educational qualification, community, designation, nature of the department they are working- in, years of experience, nature of job and average number of working hours per week.

- To find out the relationship between the occupational stress caused due to personal and professional efficiency and professional burnout of university teachers.

\section{$>$ Hypotheses of the Study}

- There exists a significant difference in the professional burnout of university teachers due to variations in their gender, age, educational qualification, community, designation, nature of the department they are working in, years of experience, nature of job and average number of working hours per week.

- There exists a significant difference in the occupational stress resulting from personal and professional efficiency of university teachers due to variations in their gender, age, educational qualification, community, designation, nature of the department they are workingin, years of experience, nature of job and average number of working hours per week. 
- There is a significant relationship between occupational stress resulting from personal and professional efficiency and professional burnout of university teachers.

\section{> Methodology:}

Considering the nature and purpose of the study, survey method was used in the study.

\section{$>$ Development of Research Tools:}

The investigator went through various tools developed previously to assess the occupational stress caused due to personal \& professional efficiency and professional burnout and also reviewed the literature related to these concepts. From the review of the research tools, it was found that both in western and Indian context a good number of tools were available to assess the occupational stress of teachers in particular and other employees in general. But there was no specific tool to assess the occupational stress of university teachers and thus the investigators developed a Rating Scale based on the 'Occupational Stress of Special Education Teachers Rating Scale' of Reddy (2007) to assess the Occupational Stress of University Teachers caused due to Personal and Professional Efficiency, comprising of 12 statements. Against each statement five gradations were given namely Strongly Disagree (SD), Disagree (D), Undecided (UD), Agree (A), Strongly Agree (SA) having the scores 1,2,3,4 and 5 respectively.

To assess the professional burnout of university teachers, the investigator adopted the Professional Burnout Rating Scale developed by Reddy (2007) to assess the burnout among special education teachers and modified the statements according to the requirements of the present study. The modified tool has 20 statements under 3 dimensions such as Emotional Exhaustion, Depersonalization and Personal Accomplishment. To measure the professional burnout among university teachers, against each statement five gradations were given namely Few Times a Year (FTY), Once a Month or Less $(\mathrm{OM})$, Few Times a Month (FTM), Once a Week (OW) and
Every Day (ED) having the scores 1, 2, 3, 4 and 5 respectively.

\section{Pilot Study:}

A pilot study was conducted to find out the validity and reliability of the tools used in the study. The content validity, face validity and intrinsic validity of the tools have been established by following scientific procedures. The calculated half-test and whole- test reliability values of the Occupational Stress caused due to Personal \& Professional Efficiency (0.70 and 0.86) and Professional Burnout ( 0.78 and 0.87 ) Rating Scales by using Split-half Method are high and thus, the tools used in the study possess high reliability indicating their suitability for the investigation.

\section{Sample and Statistical Techniques used in Study:}

For the purpose of the study, out 1500 administered tools, the investigator selected usable responses of 955 $(66 \%)$ university teachers in the faculties of Humanities, Social Science and Sciences from 9 State universities of A.P. State (5) and T.N. State (4) by using simple random sampling technique. The university teachers were contacted in person to explain the purpose of the study and the rating scales were administered to them according to their convenience to collect the data. The data were analyzed by using appropriate statistical techniques such as percentage, mean, $\mathrm{SD}$, mean $\pm 1 \mathrm{SD}$ and correlations.

\section{RESULTS AND DISCUSSION}

The major objectives of the present study is to find out the level of professional burnout and also the level of occupational stress caused due to the personal \& professional efficiency of university teachers. The mean and SD of professional burnout and occupational stress caused due to the personal \& professional efficiency scores have been calculated for each teacher working at the university level. Based on mean and SD, the number and percentage of university teachers falling under low, moderate and high levels of professional burnout scores and occupational stress caused due to the personal \& professional efficiency scores have been calculated and the same are presented in table-1.

\begin{tabular}{|c|c|c|c|}
\hline \multirow{2}{*}{} & \multicolumn{3}{|c|}{$\begin{array}{c}\text { Number and Percentage of Teachers with Low, Moderate and High } \\
\text { Level of PB and OS in due to P PE }\end{array}$} \\
\cline { 2 - 4 } & Low & Moderate & High \\
\hline & & & \\
Professional Burnout as a Whole & $127(13.30)$ & $675(70.68)$ & $153(16.02)$ \\
Personal \& Professional Efficiency & $381(39.90)$ & $436(45.65)$ & $138(14.45)$ \\
\hline
\end{tabular}

Note: Numbers mentioned in the brackets are in percentage

Table 1:- Number and Percentage of University Teachers with Low; Moderate and High Levels of Professional Burnout (PB) and Occupational Stress (OS) due to their Personal \& Professional Efficiency (PPE)

Burnout is a psychological syndrome of emotional exhaustion, depersonalization and reduced personal accomplishment that can occur among individuals who work with other people in some capacity. In the present study, when it comes to the university teachers, majority of them are experiencing moderate level of professional burnout due to emotional exhaustion (68.38\%), depersonalization $(66.07 \%)$, reduced personal accomplishment (64.82\%) and also professional burnout as a whole $(70.68 \%)$. On the whole, $16.02 \%$ of teachers i.e. 153 out of 955 teachers are experiencing high level of professional burnout and 127 teachers i.e. $13.30 \%$ are 
showing low level of professional burnout. Further it is noted that, majority of the university teachers i.e. 436 $(45.65 \%)$ out of 955 are experiencing moderate level of stress followed by $381(39.90 \%)$ teachers with low level of stress and $138(14.45 \%)$ teachers with high level of occupational stress caused due to their personal and professional efficiency.
To identify the level of professional burnout of university teachers, mean and SD for each stressor of the professional burnout dimension has been calculated for the whole sample of teachers working at university level. By using mean $\pm 1 \mathrm{SD}$, the low, moderate and high level stressors have been identified. The same procedure is followed to assess the level of occupational stress caused due to the personal \& professional efficiency of the university teachers and the results are presented in table-2 and 3.

\begin{tabular}{|c|c|c|c|}
\hline \multirow[t]{2}{*}{ S.No. } & \multirow[t]{2}{*}{ Dimensions of Professional Burnout } & \multicolumn{2}{|c|}{$\begin{array}{c}\text { Mean Scores and } \\
\text { Level of PB of } \\
\text { University Teachers }\end{array}$} \\
\hline & & MPB & LPB \\
\hline $\mathbf{I}$ & Emotional Exhaustion & & \\
\hline 1. & I am emotionally exhausted and as a result it affects my personal life & 1.69 & M \\
\hline 2. & My job often needs assessment from head, which makes me emotional & 1.67 & M \\
\hline 3. & My job demands interactions with parents, students and colleagues & 2.02 & $\mathrm{M}$ \\
\hline 4. & Due to continuous responsibility for students, I am often emotionally exhausted & 1.88 & M \\
\hline 5. & I feel that work burden thrusted on me leads to strain and emotional exhaustion & 2.03 & $\mathrm{M}$ \\
\hline 6. & As a result of entire day's work, I am really feeling tired to work for the next day & 2.14 & $\mathrm{M}$ \\
\hline 7. & The stress in working situations leads me to a completely burned out condition & 2.03 & $\mathrm{M}$ \\
\hline II. & Depersonalization & & \\
\hline 8. & My job earns a lot of respect from the society for me & 3.03 & $\mathrm{H}$ \\
\hline 9. & Lack of resources at the departmental level leads to personal dissatisfaction & 2.29 & M \\
\hline 10. & Continuous assessment in my job by superiors also leads to personal dissatisfaction & 1.72 & $\mathrm{M}$ \\
\hline 11. & The varied nature of work leads to insufficient time to take individual care for students & 1.94 & M \\
\hline 12. & Too much responsibilities trusted on me & 2.12 & $\mathrm{M}$ \\
\hline 13. & Increased degree of risk taking & 1.99 & $\mathrm{M}$ \\
\hline III. & Personal Accomplishment & & \\
\hline 14. & I have less interest to work as a university teacher & 1.52 & $\mathrm{~L}$ \\
\hline 15. & I am less enthusiastic about my work at university level & 1.60 & $\mathrm{M}$ \\
\hline 16. & I am cynical about my teaching, training and research contributions & 1.67 & M \\
\hline 17. & $\begin{array}{l}\text { I won't involve much in the work assigned to me in the university and not bothered much } \\
\text { about it }\end{array}$ & 3.19 & $\mathrm{H}$ \\
\hline 18. & I have a doubt on the significance of my work in the university & 1.86 & $\mathrm{M}$ \\
\hline 19. & Anger on those who make demands & 1.76 & $\mathrm{M}$ \\
\hline 20. & Feeling of helplessness & 2.03 & $\mathrm{M}$ \\
\hline
\end{tabular}

Note: Low-1.57 and below; Moderate - 1.58 to 2.43; \& High - 2.44 and above

Table 2:- Mean Scores and Level of Professional Burnout of University Teachers

In table-2, the mean burnout scores and level of burnout of teachers working at university level in south India are presented. The table clearly reveals that under the dimension emotional exhaustion, the aspects such as - the feeling of emotional exhaustion that affects their personal life (S.No.1), need for assessment of their job by the head (S.No.2), nature of job that demands interaction with parents, students and colleagues (S.No.3), continuous responsibility for students (S. No.4), over workload
(S.No.5), feeling tired due to entire day's work (S.No.6) and stress in the working situations (S.No.7) makes the university teachers to burnout moderately.

The table also reveals that under the depersonalization dimension, the university teachers felt that their teaching does not earn lot of respect (S.No.8) from the society which leads to their depersonalization resulting in higher rates of burnout in them. All the other factors under this dimension 
have created moderate level of burnout among university teachers. With regard to the third dimension i.e. reduced personal accomplishment, the university teachers experience high level of professional burnout in only one aspect (S.No.17) where the teachers do not show much involvement in the assigned work. In contrast, the university teachers possess high level of personal accomplishment and disregard the statement that they have less interest to work as a university teacher (S.No.14) showing low level of burnout; whereas, in all the other aspects the university teachers possess moderate level of burnout.

\begin{tabular}{|c|c|c|c|}
\hline \multirow[t]{2}{*}{ S. No. } & \multirow[t]{2}{*}{ Occupational Stress caused due to Personal \& Professional Efficiency } & \multicolumn{2}{|c|}{$\begin{array}{c}\text { Mean Scores and } \\
\text { Level of O S of } \\
\text { University } \\
\text { Teachers }\end{array}$} \\
\hline & & MOS & LOS \\
\hline 1. & Inadequate knowledge or training to meet the demands of the profession & 2.58 & M \\
\hline 2. & $\begin{array}{l}\text { Lack of opportunities for professional enhancement in the form of participating in professional } \\
\text { meetings / seminars / conferences }\end{array}$ & 2.74 & M \\
\hline 3. & Inadequate information / support to implement curricular innovations & 2.84 & M \\
\hline 4. & Lack of skills in using modern technology to enhance the quality in teaching-learning process & 2.81 & $\mathrm{M}$ \\
\hline 5. & Lack of commitment and interest to perform the job & 2.54 & $\mathrm{M}$ \\
\hline 6. & Difficulty in managing students in the classroom & 2.38 & $\mathrm{~L}$ \\
\hline 7. & Difficulty in solving the problems that arise out of work & 2.32 & $\mathrm{~L}$ \\
\hline 8. & Lack of skills in decision making process & 2.48 & M \\
\hline 9. & Unable to complete the task within a stipulated period of time & 2.63 & $\mathrm{M}$ \\
\hline 10. & Difficult to implement new procedures and policies in place of those already in practice & 2.86 & $\mathrm{M}$ \\
\hline 11. & Lack of adequate skills to publish articles in refereed journals & 2.74 & $\mathrm{M}$ \\
\hline 12. & Lack of competence to supervise and carry out individual research project & 2.46 & $\mathrm{~L}$ \\
\hline
\end{tabular}

Note: Low-2.47 and below; Moderate - 3.00 to 2.48; \& High-3.01 and above

Table 3:- Mean Scores and Level of Occupational Stress of University Teachers due to their Personal and Professional Efficiency

From table-3, it is clear that, inadequate knowledge or training to meet the demands of the profession (S.No.1), lack of opportunities for professional enhancement (S.No.2), inadequate support to implement curricular innovations (S.No.3), lack of skills in using modern technology in teaching- learning process (S.No.4), lack of commitment and interest to perform the job (S.No.5), lack of skills in decision making process (S.No.8), unable to complete the task within time (S.No.9), difficult to implement new procedures and policies in the place of those already in practice (S.No.10) and lack of adequate skills to publish articles in refereed journals (S.No.11) are the moderate stressors among university teachers. On the other hand, difficulty in managing the students in the class, difficulty in solving the problem that arises out of work and lack of competence to supervise \& carry out individual research projects (S.No.6,7\&12) are the low occupational stressors of university teachers due to their personal and professional efficiency.

To know the significant differences, if any, in the dimensions of professional burnout of university teachers due to variations in their personal and demographic variables (gender, age, educational qualification, community, designation, nature of the department they are working-in, years of experience, nature of job, and average number of working hours per week); mean and SD has been calculated for each group in a variable and $t$ / F-tests has been used appropriately to know the significant differences between/among the groups in a variable. The same procedure is adopted for occupational stress caused due to personal \& professional efficiency of university teachers and the obtained results are presented in table - 3 and 4. 
ISSN No:-2456-2165

\begin{tabular}{|c|c|c|c|c|c|c|c|c|c|c|c|c|}
\hline \multirow{3}{*}{$\begin{array}{c}\text { Independent } \\
\text { Variables / Groups }\end{array}$} & \multicolumn{12}{|c|}{ Dimensions of Professional Burnout } \\
\hline & \multicolumn{3}{|c|}{$\left(\mathbf{P B}_{1}\right)$} & \multicolumn{3}{|c|}{$\left(\mathbf{P B}_{2}\right)$} & \multicolumn{3}{|c|}{$\left(\mathbf{P B}_{3}\right)$} & \multicolumn{3}{|c|}{ PB as a whole } \\
\hline & Mean & SD & $\begin{array}{c}\mathbf{t} / \mathbf{F} \\
\text { Values } \\
\end{array}$ & Mean & SD & $\begin{array}{c}\mathbf{t} / \mathbf{F} \\
\text { Values }\end{array}$ & Mean & SD & $\begin{array}{c}\mathbf{t} / \mathbf{F} \\
\text { Values }\end{array}$ & Mean & SD & $\begin{array}{c}\mathbf{t} / \mathbf{F} \\
\text { Values } \\
\end{array}$ \\
\hline $\begin{array}{c}\text { Gender } \\
\text { Men (682) } \\
\text { Women (273) } \\
\end{array}$ & $\begin{array}{l}13.70 \\
12.88 \\
\end{array}$ & $\begin{array}{l}5.75 \\
5.41 \\
\end{array}$ & $2.03 *$ & $\begin{array}{l}13.15 \\
12.97 \\
\end{array}$ & $\begin{array}{l}4.66 \\
4.75 \\
\end{array}$ & $0.52^{\circledR}$ & $\begin{array}{l}13.84 \\
13.20 \\
\end{array}$ & $\begin{array}{l}5.54 \\
5.28 \\
\end{array}$ & $1.63^{\Theta}$ & $\begin{array}{l}40.69 \\
39.05 \\
\end{array}$ & $\begin{array}{l}13.93 \\
12.98 \\
\end{array}$ & $1.67^{\circledR}$ \\
\hline $\begin{array}{c}\text { Age } \\
28 \text { to } 37 \mathrm{yrs}(334) \\
38 \text { to } 47 \mathrm{yrs}(252) \\
48 \& \text { above }(369)\end{array}$ & $\begin{array}{l}14.09 \\
13.37 \\
12.96\end{array}$ & $\begin{array}{l}6.06 \\
5.73 \\
5.18\end{array}$ & $3.55^{*}$ & $\begin{array}{l}13.82 \\
12.96 \\
12.53\end{array}$ & $\begin{array}{l}5.12 \\
4.56 \\
4.26\end{array}$ & $6.80^{* *}$ & $\begin{array}{l}14.15 \\
14.03 \\
12.96\end{array}$ & $\begin{array}{l}5.87 \\
5.91 \\
4.68 \\
\end{array}$ & $5.00^{* *}$ & $\begin{array}{l}42.06 \\
40.36 \\
38.46 \\
\end{array}$ & $\begin{array}{l}14.81 \\
13.86 \\
12.23\end{array}$ & $6.17^{* *}$ \\
\hline $\begin{array}{l}\text { Ednl Qualification } \\
\text { PG with NET/ } \\
\text { SLET/M.Phil.(190) } \\
\text { PG with Ph.D.(765) }\end{array}$ & $\begin{array}{l}13.79 \\
13.39 \\
\end{array}$ & $\begin{array}{l}5.90 \\
5.60 \\
\end{array}$ & $\mathbf{0 . 8 8}^{\circledR}$ & $\begin{array}{l}13.64 \\
12.96 \\
\end{array}$ & $\begin{array}{l}4.99 \\
4.60 \\
\end{array}$ & $1.78^{@}$ & $\begin{array}{l}13.93 \\
13.59 \\
\end{array}$ & $\begin{array}{l}5.93 \\
5.36 \\
\end{array}$ & $0.76^{@}$ & $\begin{array}{l}41.35 \\
39.94 \\
\end{array}$ & $\begin{array}{l}14.69 \\
13.42 \\
\end{array}$ & $1.28^{\circledR}$ \\
\hline $\begin{array}{c}\text { Community } \\
\text { OC (326) } \\
\text { BC (307) } \\
\text { MBC (93) } \\
\text { SC / ST (229) } \\
\end{array}$ & $\begin{array}{l}12.83 \\
13.78 \\
15.37 \\
13.19 \\
\end{array}$ & $\begin{array}{l}5.00 \\
6.03 \\
6.46 \\
5.52 \\
\end{array}$ & $5.44 * *$ & $\begin{array}{l}12.70 \\
12.92 \\
14.35 \\
13.38 \\
\end{array}$ & $\begin{array}{l}4.18 \\
5.05 \\
4.83 \\
4.73 \\
\end{array}$ & $3.45^{*}$ & $\begin{array}{l}12.98 \\
13.66 \\
15.51 \\
13.86 \\
\end{array}$ & $\begin{array}{l}4.76 \\
5.69 \\
6.08 \\
5.71 \\
\end{array}$ & $5.37 * *$ & $\begin{array}{l}38.51 \\
40.36 \\
45.23 \\
40.42 \\
\end{array}$ & $\begin{array}{l}11.65 \\
14.83 \\
15.15 \\
13.69 \\
\end{array}$ & $5.96 * *$ \\
\hline $\begin{array}{c}\text { Designation } \\
\text { Asst. } \\
\text { Professor(472) } \\
\text { Asso. } \\
\text { Professor(199) } \\
\text { Professor (284) } \\
\end{array}$ & $\begin{array}{l}13.92 \\
12.90 \\
13.11\end{array}$ & $\begin{array}{l}5.97 \\
5.14 \\
5.44\end{array}$ & 3.12* & $\begin{array}{l}13.50 \\
13.03 \\
12.47\end{array}$ & $\begin{array}{l}4.94 \\
4.37 \\
4.39\end{array}$ & $4.33 *$ & $\begin{array}{l}13.97 \\
13.81 \\
13.04\end{array}$ & $\begin{array}{l}5.79 \\
5.28 \\
5.02\end{array}$ & $2.68^{@}$ & $\begin{array}{l}41.39 \\
39.73 \\
38.61\end{array}$ & $\begin{array}{l}14.47 \\
12.68 \\
12.85\end{array}$ & 3.83* \\
\hline $\begin{array}{c}\text { Nature of Dept. } \\
\text { Humanities (221) } \\
\text { Social } \\
\text { Sciences }(262) \\
\text { Sciences (472) }\end{array}$ & $\begin{array}{l}12.73 \\
13.68 \\
13.69\end{array}$ & $\begin{array}{l}5.28 \\
6.20 \\
5.50\end{array}$ & $2.42^{@}$ & $\begin{array}{l}12.89 \\
13.01 \\
13.24\end{array}$ & $\begin{array}{l}4.63 \\
5.17 \\
4.42\end{array}$ & $\mathbf{0 . 4 9}{ }^{@}$ & $\begin{array}{l}13.62 \\
13.79 \\
13.60\end{array}$ & $\begin{array}{l}5.76 \\
6.21 \\
4.88\end{array}$ & $0.11^{\circledR}$ & $\begin{array}{l}39.24 \\
40.48 \\
40.54\end{array}$ & $\begin{array}{c}12.1 \\
15.38 \\
12.89\end{array}$ & $0.74^{\circledR}$ \\
\hline $\begin{array}{c}\text { Years of } \\
\text { Experience } \\
1-10 \text { yrs (389) } \\
11-20 \text { yrs }(267) \\
20 \text { yrs \& above (299) }\end{array}$ & $\begin{array}{l}13.89 \\
13.03 \\
13.29\end{array}$ & $\begin{array}{l}6.04 \\
5.11 \\
5.60\end{array}$ & $\mathbf{2 . 0 4}{ }^{\circledR}$ & $\begin{array}{l}13.55 \\
12.70 \\
12.86\end{array}$ & $\begin{array}{l}5.01 \\
4.48 \\
4.38\end{array}$ & $3.15^{*}$ & $\begin{array}{l}13.92 \\
13.60 \\
13.37\end{array}$ & $\begin{array}{l}5.91 \\
5.24 \\
5.08\end{array}$ & $0.86^{@}$ & $\begin{array}{l}41.36 \\
39.34 \\
39.52\end{array}$ & $\begin{array}{l}14.54 \\
12.87 \\
13.17\end{array}$ & $2.30^{\circledR}$ \\
\hline $\begin{array}{c}\text { Nature of Job } \\
\text { Permanent (905) } \\
\text { Temporary (51) } \\
\end{array}$ & $\begin{array}{l}13.46 \\
13.63 \\
\end{array}$ & $\begin{array}{l}5.67 \\
5.46 \\
\end{array}$ & $0.21^{\circledR}$ & $\begin{array}{l}13.09 \\
13.63 \\
\end{array}$ & $\begin{array}{l}4.68 \\
5.46\end{array}$ & $0.07^{\circledR}$ & $\begin{array}{l}13.67 \\
13.49 \\
\end{array}$ & $\begin{array}{r}5.49 \\
5.119 \\
\end{array}$ & $0.22^{@}$ & $\begin{array}{l}40.22 \\
40.25 \\
\end{array}$ & $\begin{array}{l}13.74 \\
12.79 \\
\end{array}$ & $\mathbf{0 . 0 2}{ }^{@}$ \\
\hline $\begin{array}{c}\text { No.of working } \\
\text { hrs/week } \\
14 \text { hrs \& below } \\
(552) \\
15 \text { hrs \& above } \\
(403)\end{array}$ & $\begin{array}{l}13.43 \\
13.52\end{array}$ & $\begin{array}{l}5.69 \\
5.62\end{array}$ & $0.25^{\circledR}$ & $\begin{array}{l}13.13 \\
13.05\end{array}$ & $\begin{array}{l}4.68 \\
4.70\end{array}$ & $0.26^{@}$ & $\begin{array}{l}13.76 \\
13.52\end{array}$ & $\begin{array}{l}5.40 \\
5.58\end{array}$ & $\mathbf{0 . 6 8}^{\circledR}$ & $\begin{array}{l}40.32 \\
40.08\end{array}$ & $\begin{array}{l}13.63 \\
13.76\end{array}$ & $0.26^{\circledR}$ \\
\hline $\begin{array}{c}\text { State } \\
\text { A.P. State }(492) \\
\text { TN State }(463)\end{array}$ & $\begin{array}{l}12.87 \\
14.10\end{array}$ & $\begin{array}{l}5.39 \\
5.87\end{array}$ & $3.37 * *$ & $\begin{array}{l}12.46 \\
13.78\end{array}$ & $\begin{array}{l}4.37 \\
4.91\end{array}$ & $4.39 * *$ & $\begin{array}{l}12.88 \\
14.49\end{array}$ & $\begin{array}{l}4.83 \\
5.98\end{array}$ & $4.58 * *$ & $\begin{array}{l}38.20 \\
42.36\end{array}$ & $\begin{array}{l}12.80 \\
14.26\end{array}$ & $4.75 * *$ \\
\hline
\end{tabular}

Note: ** Significant at 0.01 level; * Significant at 0.05 level; @ Not significant at 0.05 level

Table 4:- Mean and SD of the Professional Burnout of University Teachers and the Calculated $\mathrm{t} / \mathrm{F}$-values with Respect to Certain Independent Variables

From table-4, it is clear that professional burnout experienced by the university teachers owing to emotional exhaustion $\left(\mathrm{PB}_{1}\right)$ differs significantly due to variation in their gender, as the calculated t-value is 2.03 which is significant at 0.05 level; whereas, the $\mathrm{t}$-value with respect to depersonalization $\left(\mathrm{PB}_{2}\right)$, reduced personal accomplishment $\left(\mathrm{PB}_{3}\right)$ and professional burnout $(\mathrm{PB})$ as a whole is $0.52,1.63$ and 1.67 respectively which are not significant at 0.05 level. Hence, the stated hypothesis, 'there is a significant difference in the dimensions of 
professional burnout of university teachers due to variations in their gender' stands rejected with respect to $\mathrm{PB}_{2}, \mathrm{~PB}_{3}$ and professional burnout as a whole but accepted only in case of $\mathrm{PB}_{1}$. The mean values indicate that men teachers are burning out at high rates than their women counterparts due to emotional exhaustion. The findings of the studies by Anderson and Iwanicki (1984) and Reddy (2007) on special education teachers corroborate with the present findings where the male teachers experience higher levels of emotional exhaustion than their female counterparts though opposed by the study results of Maslach and Jackson (1981b) on human service professionals and Byrne (1991a) on elementary and university educators where the female teachers show higher levels of emotional exhaustion than their male counterparts.

In case of the university teacher's belonging to various age groups, the calculated F-values with respect to emotional exhaustion $\left(\mathrm{PB}_{1}-3.55\right)$ is significant at 0.05 level and depersonalization $\left(\mathrm{PB}_{2}-6.80\right)$, personal accomplishment $\left(\mathrm{PB}_{3}-5.00\right)$ and professional burnout as a whole (6.17) are significant at 0.01 level. This indicates that the university teachers belonging to different age groups significantly differ in their professional burnout. Further, the mean values reveal that the university teachers belonging to lower age group i.e. 28 to 37 years exhibit higher levels of professional burnout owing to $\mathrm{PB}_{1}, \mathrm{~PB}_{2}$, $\mathrm{PB}_{3}$ and $\mathrm{PB}$ as a whole followed by middle age group and higher age group teachers. From this, one can accept the stated hypothesis, 'there is a significant difference in the dimensions of the professional burnout of the university teachers due to variations in their age'. The study results of Anderson and Iwanicki, 1984; Maslach and Jackson, 1981b; Russell et al., 1987; Schwab and Iwanicki, 1982; Schwab et al. 1986; Antoniou et al., 2006 and; Watts and Robertson, 2011, confirm the above findings where the younger teachers show higher levels of emotional exhaustion than their older colleagues. Also, Byrne (1991a) and Maslach and Jackson (1981b) reported similar findings that the elementary and university educators belonging to younger age group have lower perceptions of personal accomplishment. In case of depersonalization, the results of the studies by Maslach and Jckson (1981b) and Pierce and Molloy (1990) are similar in line with the present findings of younger age group experiencing more burnout due to depersonalization.

In case of 'community' of university teachers, the calculated F-values for emotional exhaustion $\left(\mathrm{PB}_{1}\right.$ - 5.44), depersonalization $\left(\mathrm{PB}_{2}-3.45\right)$, personal accomplishment $\left(\mathrm{PB}_{3}\right.$ - 5.37) and professional burnout as a whole (5.96) are significant at 0.05 level, indicating the influence of the nature of community of university teachers on their professional burnout owing to $\mathrm{PB}_{1}, \mathrm{~PB}_{2}, \mathrm{~PB}_{3}$ and $\mathrm{PB}$ as a whole. In other words, it can be posit that the university teachers with varied community background significantly differ in their professional burnout owing to emotional exhaustion, depersonalization, reduced personal accomplishment and professional burnout as a whole. Thus the stated hypothesis, 'there is a significant difference in the dimensions of professional burnout of university teachers due to variations in their nature of community background' is accepted. The mean values clearly reveal that the university teachers belonging to MBC experience higher levels and the teachers belonging to $\mathrm{OC}$ experience low level of professional burnout owing to $\mathrm{PB}_{1}, \mathrm{~PB}_{2}, \mathrm{~PB}_{3}$ and $\mathrm{PB}$ dimensions as a whole. In case of the dimensions $\mathrm{PB}_{2}, \mathrm{~PB}_{3}$ and $\mathrm{PB}$ as a whole, the teachers belonging to $\mathrm{SC} / \mathrm{ST}$ experience more stress followed by $\mathrm{BC}$; whereas, the teachers belonging to $\mathrm{BC}$ experience higher level of professional burnout due to emotional exhaustion when compared to SC /ST teachers.

For 'designation' of university teachers, the calculated F-values with respect to $\mathrm{PB}_{1}$ (3.12), $\mathrm{PB}_{2}$ (4.33) and $\mathrm{PB}$ as a whole (3.83) are above the table value (3.00). It reveals that the professional burnout exhibited by the university teachers because of $\mathrm{PB}_{1}, \mathrm{~PB}_{2}$ and $\mathrm{PB}$ as a whole differ significantly due to variations in their designation. Contrary to this, the variations in the university teacher's designation do not have significant bearing on their professional burnout aroused because of reduced personal accomplishment $\left(\mathrm{PB}_{3}-2.68\right)$, as the calculated F-value is below the table value (3.00). Thus the stated hypothesis, 'there is a significant difference in the dimensions of professional burnout of university teachers due to variations in their designation' is accepted with respect to $\mathrm{PB}_{1}, \mathrm{~PB}_{2}$ and $\mathrm{PB}$ as a whole and rejected only with respect to $\mathrm{PB}_{3}$. Assistant Professors experience higher level of burnout owing to emotional exhaustion, depersonalization and professional burnout as a whole followed by Associate Professors and Professors. In other words, the lower the designation, the higher will be the professional burnout. The present findings with respect to burnout are similar to the findings of the studies by Azeem and Nazir (2008) on university teachers which reports that Lecturers exhibit high levels of emotional exhaustion compared to the Readers and Professors.

The professional burnout of university teachers owing to emotional exhaustion $\left(\mathrm{PB}_{1}\right)$, personal accomplishment $\left(\mathrm{PB}_{3}\right)$ and professional burnout as a whole do not vary due to variations in their years of experience; whereas, the professional burnout owing to depersonalization $\left(\mathrm{PB}_{2}\right)$ vary based on the variations in their years of experience. Accordingly, the calculated F-values are not significant at 0.05 level with respect to $\mathrm{PB}_{1}(2.04), \mathrm{PB}_{3}(0.86)$ and $\mathrm{PB}$ as a whole (2.30), except $\mathrm{PB}_{2}$ (3.15) which is significant at 0.05 level. Thus the stated hypothesis, 'there is a significant difference in the dimensions of the professional burnout of the university teachers due to variations in their years of experience' is accepted only with respect to $\mathrm{PB}_{2}$ and rejected in case of $\mathrm{PB}_{1}, \mathrm{~PB}_{3}$ and $\mathrm{PB}$ as a whole. Further, the mean values prove that the university teachers having 1- 10 years of experience show higher levels of burnout owing to depersonalization followed by teachers having 20 and above years and 11-20 years of experience. 
Further, the calculated t-values of the university teachers working in A.P. State and T.N. States with respect to $\mathrm{PB}_{1}$ (3.37), $\mathrm{PB}_{2}$ (4.39), $\mathrm{PB}_{3}$ (4.58) and $\mathrm{PB}$ as a whole (4.75) are significant at 0.01 level. It reveals the fact that the professional burnout experienced by the university teachers owing to $\mathrm{PB}_{1}, \mathrm{~PB}_{2}, \mathrm{~PB}_{3}$ and $\mathrm{PB}$ as a whole differ significantly due to variations in the States they are working - in. Thus the formulated hypothesis, 'there is a significant difference in the dimensions of professional burnout of university teachers due to variations in the states they are working' is accepted. Further, the mean values reveal that the teachers who are working in the T.N. State universities $(12.87,12.46,12.88 \& 38.20)$ experience higher level of professional burnout due to $\mathrm{PB}_{1}, \mathrm{~PB}_{2}, \mathrm{~PB}_{3}$ and $\mathrm{PB}$ as a whole when compared to the teachers working in A.P. State universities (14.10, 13.78, $14.49 \& 42.36)$.

In contrast, the calculated $\mathrm{t} / \mathrm{F}$ values with respect to the 'educational qualification' $\left(\mathrm{PB}_{1}-0.88 ; \mathrm{PB}_{2}-1.78 ; \mathrm{PB}_{3}-\right.$ 0.76 \& PB-1.28); 'nature of the department' $\left(\mathrm{PB}_{1}-2.42\right.$; $\left.\mathrm{PB}_{2}-0.49 ; \mathrm{PB}_{3}-0.11 \& \mathrm{~PB}-0.74\right)$; 'nature of job' $\left(\mathrm{PB}_{1}-\right.$ $\left.0.21 ; \mathrm{PB}_{2}-0.07 ; \mathrm{PB}_{3}-0.22 \& \mathrm{~PB}-0.02\right)$; and 'number of working hours/week' ( $\mathrm{PB}_{1}-0.25 ; \mathrm{PB}_{2}-0.26 ; \mathrm{PB}_{3}-0.68$ \& $\mathrm{PB}$ $0.26)$ are below the table values and hence the stated hypothesis 'there is a significant difference in the dimensions of professional burnout of university teachers due to variations in the educational qualification; nature of the department; nature of job and number of working hours/week' stands rejected.

\begin{tabular}{|c|c|c|c|}
\hline \multirow[b]{2}{*}{ Independent Variables / Groups } & \multicolumn{3}{|c|}{ Occupational Stress due to Personal \& Professional Efficiency } \\
\hline & Mean & SD & $\mathrm{t} / \mathrm{F}$ Values \\
\hline $\begin{array}{c}\text { Gender } \\
\text { Men }(682) \\
\text { Women }(273) \\
\end{array}$ & $\begin{array}{l}31.75 \\
30.46 \\
\end{array}$ & $\begin{array}{l}11.26 \\
10.43 \\
\end{array}$ & $1.64^{@}$ \\
\hline $\begin{array}{c}\text { Age Groups } \\
28 \text { to } 37 \text { yrs }(334) \\
38 \text { to } 47 \text { yrs }(252) \\
48 \& \text { above }(369) \\
\end{array}$ & $\begin{array}{l}31.23 \\
30.84 \\
31.89 \\
\end{array}$ & $\begin{array}{l}11.28 \\
10.31 \\
11.30 \\
\end{array}$ & $\mathbf{0 . 7 3}^{@}$ \\
\hline $\begin{array}{c}\text { Educational Qualification } \\
\text { PG with NET/SLET/M.Phil.(190) } \\
\text { PG with Ph.D.(765) }\end{array}$ & $\begin{array}{l}30.90 \\
31.50 \\
\end{array}$ & $\begin{array}{l}10.42 \\
11.19 \\
\end{array}$ & $0.67^{@}$ \\
\hline $\begin{array}{c}\text { Community } \\
\text { OC (326) } \\
\text { BC (307) } \\
\text { MBC (93) } \\
\text { SC / ST (229) } \\
\end{array}$ & $\begin{array}{l}31.87 \\
29.93 \\
33.09 \\
31.93\end{array}$ & $\begin{array}{l}11.51 \\
10.75 \\
10.72 \\
10.71\end{array}$ & $2.93 *$ \\
\hline $\begin{array}{c}\text { Designation } \\
\text { Assistant Professor(472) } \\
\text { Associate Professor(199) } \\
\text { Professor (284) } \\
\end{array}$ & $\begin{array}{l}30.89 \\
32.69 \\
31.28 \\
\end{array}$ & $\begin{array}{l}10.31 \\
11.63 \\
11.72 \\
\end{array}$ & $1.89^{@}$ \\
\hline $\begin{array}{c}\text { Nature of Dept. } \\
\text { Humanities }(221) \\
\text { Social Sciences(262) } \\
\text { Sciences (472) } \\
\end{array}$ & $\begin{array}{l}29.81 \\
30.36 \\
32.69 \\
\end{array}$ & $\begin{array}{l}11.57 \\
10.65 \\
10.86 \\
\end{array}$ & $6.75 * *$ \\
\hline $\begin{array}{c}\text { Years of Experience } \\
1-10 \text { years }(389) \\
11-20 \text { years }(267) \\
20 \text { years \& above }(299) \\
\end{array}$ & $\begin{array}{l}30.61 \\
31.41 \\
32.36 \\
\end{array}$ & $\begin{array}{l}10.86 \\
11.21 \\
11.07 \\
\end{array}$ & $2.12^{@}$ \\
\hline $\begin{array}{c}\text { Nature of Job } \\
\text { Permanent }(905) \\
\text { Temporary }(51) \\
\end{array}$ & $\begin{array}{l}31.45 \\
30.18 \\
\end{array}$ & $\begin{array}{c}11.11 \\
9.61\end{array}$ & $0.80^{@}$ \\
\hline $\begin{array}{c}\text { No. of working hours/week } \\
14 \text { hours \& below (552) } \\
15 \text { hours \& above (403) } \\
\end{array}$ & $\begin{array}{l}31.82 \\
30.78 \\
\end{array}$ & $\begin{array}{l}11.03 \\
11.08 \\
\end{array}$ & $1.44^{@}$ \\
\hline $\begin{array}{c}\text { State } \\
\text { A.P. State (492) } \\
\text { TN State }(463)\end{array}$ & $\begin{array}{l}31.32 \\
31.44\end{array}$ & $\begin{array}{l}10.54 \\
11.55\end{array}$ & $0.17^{@}$ \\
\hline
\end{tabular}

Note: ** Significant at 0.01 level; * Significant at 0.05 level ; @ Not significant at 0.05 level

Table 5:- Mean and SD of the Occupational Stress of University Teachers caused due to Personal \& Professional Efficiency and the calculated t / F-values with respect to Certain Independent Variables 
From table-5 it is clear that the teachers working at university level do not differ significantly in their occupational stress caused due to personal \& professional efficiency in certain variables as the calculated $\mathrm{t} / \mathrm{F}$ values with respect to their gender (1.64), age (0.73), educational qualification (0.67), designation (1.89), years of experience (2.12), nature of job (0.80), number of working hours/week $(1.44)$ and the state universities they are working in $(0.17)$ respectively are not significant at 0.05 level. Whereas, the teachers differ significantly in their Occupational Stress caused due to Personal \& Professional Efficiency in two variables as their calculated $\mathrm{t} / \mathrm{F}$-value with respect to community (2.93) and nature of the department (6.75) are significant at 0.05 level and 0.01 level respectively. Hence the stated hypothesis 'there is a significant difference in the Occupational Stress caused due to the Personal \&
Professional Efficiency of the university teachers due to variations in certain variables like gender, age, educational qualification, designation, years of experience, nature of job, number of working hours/week and the state universities they are working-in' stands rejected; and accepted only for the two variables such as 'community' and 'the nature of the department'.

One of the objectives of the study is to find out the relationship between the occupational stress caused due to personal \& professional efficiency and professional burnout of university teachers. To realize this objective, Karl Pearson's Co-efficient of correlations has been computed based on university teacher's occupational stress due to personal \& professional efficiency and professional burnout dimensions and the same has been shown in table- 6 .

\begin{tabular}{|c|c|c|c|c|}
\hline $\begin{array}{c}\text { O.S. } \\
\text { P.B. }\end{array}$ & $\begin{array}{c}\text { Emotional } \\
\text { Exhaustion }\end{array}$ & Depersonalization & Personal Accomplishment & $\begin{array}{c}\text { Professional Burnout as } \\
\text { a Whole }\end{array}$ \\
\hline $\begin{array}{c}\text { Personal \& } \\
\text { Professional } \\
\text { Efficiency }\end{array}$ & $0.169^{* *}$ & $0.212^{* *}$ & $0.210^{* *}$ & $0.227^{* *}$ \\
\hline
\end{tabular}

Note: ** Significant at 0.01 level

Table 6:- Correlation between the Dimensions of Professional Burnout of University Teachers and the Occupational Stress due to their Personal \& Professional Efficiency

In table-6, it is observed that, the occupational stress caused due to personal \& professional efficiency has significant and positive relationship with all the dimensions of the professional burnout i.e. emotional exhaustion (0.169), depersonalization (0.212), personal accomplishment (0.210) and professional burnout as a whole (0.227), as the calculated r-values are significant at 0.01 level. It means, higher the OS caused due to personal $\&$ professional efficiency, higher will be the professional burnout. Thus the stated hypothesis, 'there is a significant positive relationship between the occupational stress caused due to personal \& professional efficiency and the dimensions of the professional burnout of the teachers working in the universities of south India' is accepted.

\section{IMPLICATIONS OF THE STUDY}

The effects of stress and burnout of teachers are costly to both the teacher as well as the organization if left unattended within a given time frame. These can lead to poor teaching performance, lowered self-esteem, poor job satisfaction, increased absenteeism, poor decision making and bad judgment (Quick and Quick, 1984). From the results of the present investigation it was found that, around 86 percent of university teachers are experiencing moderate and high levels of professional burnout and around 60 percent of them are showing moderate and high level of occupational stress due to their personal \& professional efficiency. This indicates the need for interventions in strengthening and reinforcing teacher's self-confidence and positive attitude, and weakening the stress and burnout creating factors. Stress and burnout of job life can be conveniently managed, to a large extent, at different stages through institutional interventions.

$>$ Prevention of stress and burnout through organizational interventions at the management level like - selection of suitably qualified teachers, proper job designing and training, adequate work conditions, effective supervision and incentive system, effective communication system, participative management, etc.

$>$ Frequency and intensity of stressful situations integral to the job at the organizational level needs to be minimized by moderating the intensity of integral job stressors and their consequent strains through the effect of other variables of positive values, such as high or extra salary, non-financial incentives, social support, generating team feeling, participative decision making, etc. at departmental, school and university level.

$>$ Much of the stress and burnout can be minimized through support, persistence, problem solving, active decision making and planning, organizational adaptability and developing good human relations. The teachers' of today are undergoing tremendous pressure and burnout in their professional life. If they are to face the problems of their profession with confidence and courage, a positive attitude towards life, high level of emotional intelligence to provide a new ways to understand and assess people's behaviors, management styles, and interpersonal skills are essential. Potential and optimum level of stress will help the person to cope with his personal and professional life, which results in good performance in his / her job. 
The qualities which are considered crucial for teachers these days are many like; listening and verbal communication, adaptability and creative responses to setbacks and obstacles, personal management, confidence, motivation to work towards goals, a sense of wanting to develop one's career and taking pride in accomplishment, group and inter- personal effectiveness, co-operation and team work, skills in solving disagreements, willingness to make a contribution, leadership potential are to be developed at the study and research period itself.

\section{REFERENCES}

[1]. Anderson, M.B. and Iwanicki, E.F. (1984) Teacher motivation and its relationship to teachers burnout, Educational Administration Quarterly, 20, 94-132.

[2]. Antoniou, A.-S., Polychroni, F. and Vlachakis, A.-N. (2006) Gender and age differences in occupational stress and professional burnout between primary and high-school teachers in Greece, Journal of Managerial Psychology, 21 (7), 682 - 690.

[3]. Anuradha, R.V. (2012) Emotional Intelligence, Occupational Stress and Job Performance of Teachers Working at Higher Secondary Level, Ph.D. Thesis, Dravidian University, Kuppam.

[4]. Azeem, S.M. and Nazir, N.A. (2008) A study of job burnout among university teachers, Psychology \& Developing Societies, 20 (1), 51-64.

[5]. Bandura, A. (1997). Self-Efficacy: The exercise of control. Freeman and Company, New York, W. H.

[6]. Byrne, B.M. (1991a). Burnout : Investigating the impact of background variables for elementary, intermediate, secondary and university educators, Multivariate Behavioral Research, 26, 583-605.

[7]. Chan, D.W. (1998) Stress, coping strategies and psychological distress among secondary school teachers in Hong Kong, American Educational Research Journal, 35 (1), Pp. 145-163.

[8]. Comish, R. and Swindle, B. (1994) Managing stress in the workplace, National Public Accountant, 39 (2), Pp. 24-28.

[9]. Cooper, C.L. and Kelly, M. (1993) Occupational stress of head teachers: A national UK study, British Journal of Educational Psychology, 73 (1), Pp. 130143.

[10]. Cordes, C. L. and Dougherty, T. M. (1993) A review and integration of research on job burnout, Academy of Management Review, 18, 621-656.

[11]. Evers, W. J. G. and Tomic, W. (2003) Student's perceptions of the incidence of burnout among their teachers, Research in Education, 69, 1-15.

[12]. Foqua, R. and Couture, K. (1986) Burnout and locus of control in child care staff, Child Care Quarterly, 15 (2), 98-102.

[13]. Guskey, T.R. (1984) The influence of change in instructional effectiveness upon the affective characteristics of teachers. American Educational Research Journal, 21, 245-259.
[14]. Hall, D.T. and Associates (1996) The career is dead: Long live the career, Jossey-Bass: San Francisco.

[15]. Houston, D., Meyer-Luanna, H. and Paewai, S. (2006) Academic staff workloads and job satisfaction: expectations and values in academe, Journal of Higher Education Policy and Management, 28 (1), 1730.

[16]. Hsieh, C. J., Hsieh, H.Y., Chen, P. H, Hsiao, Y. L. and Lee, S. (2004) The relationship between hardiness, coping strategies and burnout in psychiatric nurses, Hu Li Za Zhi (The journal of Nursing), 51 (3), 24-33.

[17]. Kobasa, S. C. (1979). Stressful life events, personality and health: An inquiry into hardiness, Journal of Personality and Social Psychology, 37 (1), 1-11.

[18]. Leiter, M. (1993). Burnout as a developmental process : Consideration of models. In W. Schaufeli, C. Maslach and T. Marek (Eds.), Professional burnout : Recent developments in theory and research. (pp. 237250), Taylor and Francis, Washington, DC.

[19]. Maslach, C. and Jackson, S. (1981b) The measurement of experienced burnout, Journal of Occupational Behavior, 2, 99-113.

[20]. McLaughlin, M. W., Pfeifer, R.S., Swanson-Owens, D. and Yee, S. (1986). Why teachers won't teach, Phi Delta Kappan, 67, 420-426.

[21]. Mokdad, M. (2005) Occupational stress among Algerian teachers, African Newsletter on Occupational Health and Safety, 15, Pp. 46-47.

[22]. Pierce, M.B. and Molloy, G.N. (1990) Psychological and biographical differences between secondary school teachers experiencing high and low levels of burnout, British Journal of Educational Psychology, 60, 37-51.

[23]. Quick, J.C. and Quick, J.D. (1984) Organizational stress and preventive management, McGraw-Hill: New York.

[24]. Reddy, G. L. (2007). Occupational stress, professional burnout and job satisfaction of special education teachers, Major Research Project (Report Submitted to Ministry of Social Justice and Empowerment, Govt., of India, New Delhi), Dept., of Education, Periyar University, Salem.

[25]. Reglin, G. and Reitzammer, R.A. (1997) Dealing with the stress of teachers, Education, 118 (4), Pp. 590597.

[26]. Russell, D.W., Altmaier, E. and Van Velzen, D. (1987) Job-related stress, social support and burnout among classroom teachers, Journal of Applied Psychology, 72 (2), 269-74.

[27]. Schaufeli W. B., Maslach C. and Marek T. (1993) Professional burnout: Recent developments in theory and research. Taylor \& Francis, Washington, DC.

[28]. Schaufeli, W. B., Van Dierendonck, D. and Van Gorp, K. (1996) Burnout and reciprocity: Towards a duallevel social exchange model, Work \& Stress, 10, 224237. 
[29]. Schwab, R.L. and Iwanicki, E.F. (1982) Who are our burned out teachers ?, Educational Research Quarterly, 7, 5-16.

[30]. Schwab, R.L., Jackson, S.E. and Schuler, R.A. (1986) Educator burnout : Sources and consequences, Educational Research Journal, 20 (3), 14-30.

[31]. Schwarzer, R. and Schmitz, G. S. (2005) Perceived self-efficacy and teacher burnout: a longitudinal study in ten schools, Research paper, Freie Universitat Berlin, Germany.

[32]. Taylor, F.W. (1911) Principles of scientific management, Harper and Row: New York.

[33]. Watts, J. and Robertson, N. (2011) Burnout in university teaching staff: a systematic literature review, Educational Research, 53 (1), 33 - 50, DOI: 10.1080/00131881.2011.552235 